\title{
Asymptomatic Cryptosporidium infections in ewes and lambs are a source of environmental contamination with zoonotic genotypes of Cryptosporidium parvum
}

\author{
Léa Bordes $^{1, *}$, Pauline Houert ${ }^{1}$, Damien Costa $^{2}$, Loïc Favennec ${ }^{2}$, Corinne Vial-Novella ${ }^{3}$, Francis Fidelle ${ }^{3}$, \\ Christelle Grisez ${ }^{1}$, Françoise Prévot ${ }^{1}$, Philippe Jacquiet ${ }^{1}$, and Romy Razakandrainibe ${ }^{2}$ \\ ${ }^{1}$ IHAP, UMT Pilotage de la Santé des Ruminants, Université de Toulouse, INRAE, ENVT, 31076 Toulouse, France \\ 2 Centre Hospitalier Universitaire, Centre National de Référence - Laboratoire Expert des Cryptosporidioses, 76031 Rouen, France \\ ${ }^{3}$ Centre Départemental pour l'Elevage Ovin, Quartier Ahetzia, 64130 Ordiarp, France
}

Received 12 June 2020, Accepted 19 October 2020, Published online 3 November 2020

\begin{abstract}
Protozoan parasites of the Cryptosporidium genus cause severe cryptosporidiosis in newborn lambs. However, asymptomatic infections also occur frequently in lambs and ewes. In sheep, the most commonly detected Cryptosporidium species are C. ubiquitum, C. xiaoi and C. parvum. Due to a lack of relevant information about such infections in France, we investigated the situation on five dairy sheep farms in the Pyrénées-Atlantiques Department in south-western France in December 2017. Individual fecal samples were collected from 79 female lambs (5-17 days old) and their mothers (72 ewes). Oocysts were screened using Heine staining before and after Bailenger concentrations. Cryptosporidium species identification and genotyping were performed using real-time PCR and gp60 gene sequencing. No cases of clinical cryptosporidiosis were observed in the 79 lambs. Microscopically, Cryptosporidium spp. oocysts were observed in only one lamb on one farm (prevalence 1.3\%) and one ewe on another farm (prevalence 1.4\%). By contrast, Cryptosporidium spp. DNA was detected in 17 ewes (prevalence ranging from 10.5\% to 50\% depending on the farm) and in 36 lambs (prevalence ranging from $0 \%$ to $77.8 \%$ depending on the farm). Only zoonotic Cryptosporidium parvum IId and IIa genotypes were identified when genotyping was possible. Cryptosporidium ubiquitum and $C$. xiaoi were detected on one and three farms, respectively. We conclude that healthy young lambs and their mothers during the peripartum period could be a source of environmental contamination with oocysts.
\end{abstract}

Key words: Cryptosporidium parvum, Lamb, Ewe, Zoonotic genotypes, PCR, Asymptomatic infection.

Résumé - Les infections asymptomatiques par Cryptosporidium chez les brebis et les agneaux sont une source de contamination environnementale par les génotypes zoonotiques de Cryptosporidium parvum. Les parasites protozoaires du genre Cryptosporidium provoquent une cryptosporidiose sévère chez les agneaux nouveau-nés. Cependant, des infections asymptomatiques surviennent aussi fréquemment chez les agneaux et les brebis. Chez les ovins, les espèces de Cryptosporidium les plus couramment détectées sont C. ubiquitum, C. xiaoi et C. parvum. En raison d'un manque d'informations pertinentes sur ces infections en France, nous avons enquêté sur la situation de cinq élevages ovins laitiers des Pyrénées-Atlantiques en décembre 2017. Des échantillons fécaux individuels ont été collectés sur 79 agnelles (5 à 17 jours) et leurs mères (72 brebis). Les oocystes ont été criblés en utilisant une coloration Heine avant et après concentration par la technique de Bailenger. L'identification et le génotypage des espèces de Cryptosporidium ont été réalisés à l'aide de la PCR en temps réel et du séquençage du gène gp60. Aucun cas de cryptosporidiose clinique n'a été observé chez les 79 agneaux. Au microscope, les oocystes de Cryptosporidium spp. n'ont été observés que chez un agneau dans une ferme (prévalence 1,3\%) et chez une brebis dans une autre ferme (prévalence 1,4\%). En revanche, de l'ADN de Cryptosporidium spp. a été détecté chez 17 brebis (prévalence allant de $10,5 \%$ à $50 \%$ selon les fermes) et chez 36 agneaux (prévalence variant de $0 \%$ à $77,8 \%$ selon les fermes). Seuls les génotypes zoonotiques de Cryptosporidium parvum IId et IIa ont été identifiés lorsque le génotypage était possible. Cryptosporidium ubiquitum et $C$. xiaoi ont été détectés respectivement dans une et trois fermes. Nous concluons que les jeunes agneaux en bonne santé et leurs mères, autour de l'agnelage, pourraient être une source de contamination environnementale par les oocystes.

\footnotetext{
*Corresponding author: lea.bordes@envt.fr
} 


\section{Introduction}

Cryptosporidium spp. are ubiquitous protozoan parasites, responsible for the gastrointestinal disease cryptosporidiosis. Species of Cryptosporidium can infect a wide range of vertebrate hosts, including humans. Cryptosporidium infection is one of the leading causes of diarrhea morbidity and mortality in children younger than five years and is associated with severe life-threatening illness among immunocompromized patients $[18,22,45]$. Cryptosporidium oocysts shed with the feces of a host are immediately infective. Infection with Cryptosporidium oocysts can be acquired through (i) the fecal-oral route, (ii) contaminated water or food, or (iii) aerosolized droplets or by contact with fomites contaminated by coughing [35]. Some species, such as Cryptosporidium parvum, appear to lack host specificity as they can be found in a wide range of hosts. In fact, the latter species display considerable adaptation abilities due to their high genetic variability [12]. Cryptosporidiosis has become a public health and veterinary concern as livestock can act as a reservoir and source of zoonotic cryptosporidiosis [53]. Livestock, young calves, lambs and goat kids are highly susceptible to the parasite and can develop severe diarrhea with high mortality rates, causing significant economic losses associated with anorexia, impaired growth, and death of the animal [41]. The infection can spread on the farm via the fecal-oral route by environmental contamination and animal interactions, such as during suckling $[32,52,54]$. The major sources of contamination for humans are drinking and recreational waters contaminated by livestock [11] or infected humans. However, few clinical human cryptosporidiosis cases can be explained by environmental contamination with sheep and goat manure due to the difficulty of tracking down the initial source of contamination [38]. In their model, Vermeulen and colleagues [49] estimated the Cryptosporidium oocyst loads in livestock manure and predicted that it was the main source of environmental contamination in Europe and North America. Without adequate control, this contamination represents a human health hazard, because animals infected with $C$. parvum could be excreting up to $10^{7}$ oocysts per gram of feces [11].

Clinical infections have been extensively investigated, especially in calves [3, 44, 47]; however, the prevalence of asymptomatic parasite infections and their consequences are less well documented. A few studies have investigated the prevalence of asymptomatic Cryptosporidium spp. infections in calves, sheep and goats [33, 38, 40, 52], and underlined the importance of identifying the species and genotypes involved to control zoonotic disease and environmental contamination better.

To assess the prevalence of Cryptosporidium spp. infections in humans or animals, fecal samples are tested. Various methods can be used, such as microscopic staining methods or immunofluorescence detection. These approaches are easy to use and require only basic laboratory equipment but are less sensitive [5] compared to molecular methods. They also require technical expertise, for a result that remains subjective. Molecular methods were developed to increase the sensitivity and specificity of diagnosis and to provide species-level information and the genotype of the parasite. PCR assays, targeting the 18S rRNA gene, are used for species-level identification [21]. To provide further information, molecular genotyping techniques have been developed. It is useful to identify genotypes of potential anthropozoonotic and zoonotic transmission.

In France, many studies have investigated Cryptosporidium spp. infections in livestock, especially in goat kids $[4,8,35]$ and in calves [9, 23, 38, 39]. Still, scarce data are currently available in the literature regarding Cryptosporidium infections in lambs and sheep.

The aim of this study was, therefore, to investigate the prevalence and zoonotic potential of asymptomatic Cryptosporidium spp. infections in postpartum ewes and neonatal lambs on farms in the Pyrénées-Atlantiques Department of south-western France.

\section{Materials and methods}

\section{Ethics statement}

Before carrying out this work, informed written authorization to perform and to publish the present epidemiological study anonymously was obtained from all owners. Stool collection is a part of routine veterinary procedures without any traumatic method. Such procedures are not qualified as animal experimentation involving vertebrates according to French laws, and no specific ethical clearance was required.

\section{Fecal samples from lambs and ewes}

In December 2017, the presence of Cryptosporidium spp. was investigated on five volunteer farms rearing Blond-Faced Manech dairy sheep in the French Basque Country, part of the Pyrénées-Atlantiques Department. All were mixed farms with a dairy sheep flock and a beef cattle herd. On the five farms studied, grouped artificial inseminations were performed to have only one lambing period per year. Ewes came inside a month before lambing and remained indoors until lambs were weaned at 1 and a half months. Regarding breeding practices, lambs on farm \#3 were separated from their mothers immediately after receiving colostrum and then fed artificially. On the contrary, animal management practices were apparently identical within farms \#1, \#2, \#4 and \#5: lambs were born in the shed and stayed with their mother until they were 1.5 months old, before being separated from them. On all farms, lambs remained indoors during this study. In total, 79 female lambs, aged from 5 to 17 days and their mothers (72 ewes) were tested during the study. From each farm, 8-20 female lambs and 9-19 ewes were analyzed (Table 1). For each animal, an individual fecal sample was obtained by rectal stimulation, and the clinical status was evaluated and recorded, especially signs of diarrhea. Fecal samples were stored at $4{ }^{\circ} \mathrm{C}$ before microscopic and molecular analysis.

\section{Microscopic detection of Cryptosporidium spp. oocysts in fecal samples}

The presence of Cryptosporidium spp. in fecal samples was determined using Heine staining by direct examination [34] and 
Table 1. Prevalence of Cryptosporidium infections in lambs and ewes determined by molecular analysis.

\begin{tabular}{|c|c|c|c|c|c|}
\hline \multirow[t]{2}{*}{ Farms } & \multirow[t]{2}{*}{ Animals } & \multirow{2}{*}{$\begin{array}{l}\text { Number } \\
\text { examined }\end{array}$} & \multicolumn{2}{|c|}{ Animals positive for Cryptosporidium species } & \multirow[t]{2}{*}{ Cryptosporidium parvum genotyping } \\
\hline & & & $\begin{array}{c}18 S \text { rRNA } \\
\text { gene-based PCR }\end{array}$ & $\begin{array}{l}\text { Lib13 locus and } 18 S \text { rRNA } \\
\text { sequence analysis }\end{array}$ & \\
\hline \multirow[t]{2}{*}{$\overline{\# 1}$} & Lambs & 20 & $13(65 \%)$ & $13 \mathrm{ND}$ & \\
\hline & Ewes & 18 & $3(16.7 \%)$ & $\begin{array}{l}2 \text { C. } \text { parvum }^{*} \\
1 \mathrm{ND}\end{array}$ & $\begin{array}{l}1 \text { C. parvum } \mathrm{IIdA} 21 \mathrm{G} 2 \\
1 \text { C. parvum } \mathrm{IIdA} 15 \mathrm{G} 1\end{array}$ \\
\hline \multirow[t]{2}{*}{ \#2 } & Lambs & 8 & $4(50 \%)$ & $\begin{array}{l}1 \text { C. xiaoi } \\
3 \mathrm{ND}\end{array}$ & \\
\hline & Ewes & 9 & $3(33.3 \%)$ & $\begin{array}{l}1 \text { C. parvum* } \\
1 \text { C. ubiquitum } \\
1 \mathrm{ND}\end{array}$ & $1 \mathrm{ND}$ \\
\hline \multirow[t]{2}{*}{ \#3 } & Lambs & 18 & $14(77.8 \%)$ & $\begin{array}{l}2 \text { C. } \text { parvum }^{*} \\
12 \mathrm{ND}\end{array}$ & 2 C. parvum $\mathrm{IIdA} 24 \mathrm{G} 1$ \\
\hline & Ewes & 10 & $5(50 \%)$ & $\begin{array}{l}1 \text { C. xiaoi } \\
4 \mathrm{ND}\end{array}$ & \\
\hline \multirow[t]{2}{*}{ \#4 } & Lambs & 13 & 0 & & \\
\hline & Ewes & 16 & $2(12.5 \%)$ & $\begin{array}{l}\text { 1C. parvum* } \\
1 \mathrm{ND}\end{array}$ & 1 C. parvum $\mathrm{IIaA} 16 \mathrm{G} 3 \mathrm{R} 1$ \\
\hline \multirow[t]{2}{*}{$\# 5$} & Lambs & 20 & $5(25 \%)$ & $\begin{array}{l}2 \text { C. } \text { parvum }^{*} \\
3 \mathrm{ND}\end{array}$ & $2 \mathrm{ND}$ \\
\hline & Ewes & 19 & $2(10.5 \%)$ & 2 C. parvum $^{*}$ & $\begin{array}{l}1 \text { C. parvum } \mathrm{IIaA} 16 \mathrm{G} 3 \mathrm{R} 1 \\
1 \text { C. parvum } \mathrm{IIaA} 13 \mathrm{G} 2 \mathrm{R} 1\end{array}$ \\
\hline \multirow[t]{2}{*}{ Total } & Lambs & 79 & $36(45.6 \%)$ & $\begin{array}{l}4 \text { C. } \text { parvum }^{*} \\
1 \text { C. xiaoi } \\
31 \mathrm{ND}\end{array}$ & 2 C. parvum IIdA24G1 \\
\hline & Ewes & 72 & $17(23.6 \%)$ & $\begin{array}{l}6 \text { C. parvum* } \\
3 \text { C. xiaoi } \\
1 \text { C. ubiquitum } \\
7 \text { ND }\end{array}$ & $\begin{array}{l}2 \text { C. parvum } \mathrm{IIaA} 16 \mathrm{G} 3 \mathrm{R} 1 \\
1 \text { C. parvum } \mathrm{IIdA} 21 \mathrm{G} 2 \\
1 \text { C. parvum } \mathrm{IIdA} 15 \mathrm{G} 1 \\
1 \text { C. } \text { parvum } \mathrm{IIaA} 13 \mathrm{G} 2 \mathrm{R} 1\end{array}$ \\
\hline
\end{tabular}

ND: not determined due to sequencing failure." Determined by Lib13 PCR result.

after Bailenger concentration [1]. Briefly, for the negative staining technique of Heine, $10 \mu \mathrm{L}$ of fecal matter with no preservative were mixed with an equal amount of undiluted carbol-fuchsine solution on a microscope slide. A thin smear was prepared, allowed to air dry and examined within $15 \mathrm{~min}$ under phase-contrast microscope, a hundred microscopic fields were observed using an oil-immersion objective of $\times 40$ magnification. Cryptosporidium oocysts appear as unstained, strongly refractive, round to oval structures of about 3-6 $\mu \mathrm{m}$ in diameter. The presence of other intestinal parasites (Giardia, Strongyloides, and amoeba) detected in some of the ewe and lamb fecal samples was not considered in the present study.

\section{Cryptosporidium species identification and genotyping}

All samples were analyzed by molecular methods for species identification, and positive samples were genotyped in a second step. Samples were prepared as described by Razakandrainibe and colleagues [38]. Briefly, $250 \mathrm{mg}$ of feces were pre-treated using mechanical lysis in Lysing Matrix A Tubes (Qiagen, CA, USA), thermal shock lysis and sonication before isolating DNA from the pre-treated samples using a modified QIAmp Stool Mini Kit (Qiagen, CA, USA).

Cryptosporidium species were screened using realtime PCR targeting the $18 S$ rRNA and LIB13 genes, as described by Hadfield and colleagues [17]. Briefly, PCR was carried out in duplicate and consisted of two duplex reactions: (i) a genusspecific PCR amplifying 300 bp of the Cryptosporidium $18 s$ rRNA gene, duplexed with a $C$. parvum-specific PCR amplifying 166 bp of the LIB13 locus, and (ii) a C. hominis-specific PCR amplifying $169 \mathrm{bp}$ of the LIB13 locus.

Thermocycling conditions were as follows: $95{ }^{\circ} \mathrm{C}$ for $10 \mathrm{~min}$, followed by 55 cycles of $95{ }^{\circ} \mathrm{C}$ for $15 \mathrm{~s}$ and $60{ }^{\circ} \mathrm{C}$ for $60 \mathrm{~s}$. Data were collected from each probe channel during each $60{ }^{\circ} \mathrm{C}$ annealing/extension phase.

Samples positive with the species-specific probes were then further characterized by examining the gp60 gene. However, as the primers commonly used for gp60 subtyping of $C$. parvum and $C$. hominis do not reliably amplify many other Cryptosporidium species, DNA samples that only reacted with the genus-specific probes were also sequenced at the $18 S \mathrm{rRNA}$ gene for species identification.

Genotyping was performed by sequencing a fragment of the gp60 gene. Primers AL3531 and AL3533 were used in the primary PCR and primers AL3532 and LX0029 in the secondary PCR, leading to amplification of a fragment of approximately 364 bp [16]. Each PCR mixture (total volume, $50 \mu \mathrm{L})$ contained $5 \mu \mathrm{L}$ of $10 \mathrm{X}$ DreamTaq Buffer, each deoxynucleoside triphosphate at a concentration of $0.2 \mathrm{mM}$, each primer at a concentration of $100 \mathrm{nM}, 2.5 \mathrm{U}$ of DreamTaq polymerase, and five microliters of DNA template. Also, 
$1.25 \mu \mathrm{L}$ of DMSO (100\%) were added to the mixture. A total of 40 cycles, each consisting of $94{ }^{\circ} \mathrm{C}$ for $45 \mathrm{~s}, 55^{\circ} \mathrm{C}$ for $45 \mathrm{~s}$, and $72{ }^{\circ} \mathrm{C}$ for $1 \mathrm{~min}$, were performed. An initial hot start at $94{ }^{\circ} \mathrm{C}$ for $3 \mathrm{~min}$ and a final extension step at $72{ }^{\circ} \mathrm{C}$ for 7 min were also included. Each amplification run included a negative control (PCR water) and two positive controls (genomic DNA from purified C. parvum oocysts (from experimentally infected calves) purchased from Waterborne Inc., and C. hominis genomic DNA from a fecal specimen collected in Rouen University Hospital). Products were visualized in $2 \%$ agarose gels using ethidium bromide staining. Positive samples were further genotyped by DNA sequencing of the gp60 gene.

Sequencing was used to confirm Cryptosporidium species/genotypes from second-round PCR products. PCR amplicons were purified using Exonuclease I/Shrimp Alkaline Phosphatase (Exo-SAP-IT) (USB Corporation, OH, USA), and were sequenced in both directions using the same PCR primers at $3.2 \mu \mathrm{M}$ in $10 \mu \mathrm{L}$ reactions, Big Dye ${ }^{\mathrm{TM}}$ chemistries, in an ABI 3500 sequence analyzer (Applied Biosystems, CA, USA). Sequence chromatograms of each strand were examined with 4 peaks software and compared with published sequences in the GenBank database using BLAST (https://www.ncbi.nlm. nih.gov/BLAST). Genotypes were named using the established gp60 genotype nomenclature [46]. The sequences obtained in this study were deposited in GenBank under the accession numbers MT418843-MT418848. In case of failure in species/ genotype identification, ND (not determined) was annotated to the corresponding isolate in Table 1.

\section{Statistical analysis}

Statistical analyses were performed with $\mathrm{R}$ software, version 3.6.3 (2020/02/29) using $\mathrm{R}$ studio, version 12.5033. A Fisher's exact test was used to compare the prevalence of cryptosporidiosis between farms and animal categories.

\section{Results}

Microscopically, results showed a low prevalence of animals infected with the parasite: oocysts were detected in only one lamb (1.3\%) on farm \#5 and one ewe (1.4\%) on farm \#2. Molecular characterization showed that $C$. ubiquitum infected the lamb; however, identification of the Cryptosporidium species infecting the ewe was unsuccessful due to an unreadable sequence (peaks unevenly spaced, nucleotide bases were not deciphered correctly). At the farm level, the prevalence ranged between $0 \%$ and $5 \%$ for lambs, and between $0 \%$ and $11.1 \%$ for ewes. During this study, no clinical cases of cryptosporidiosis were observed.

The results of the PCR analyses (species identification and genotyping) are provided in Table 1 . Out of the five investigated farms, four were found to have asymptomatic cryptosporidiosis in lambs: only farm \#4 was free of Cryptosporidium DNA in lamb feces. In ewes, Cryptosporidium DNA was detected on all of the studied farms. The prevalence of Cryptosporidium infection was higher with PCR analysis than with microscopic examination of feces, regardless the farm considered. The $18 \mathrm{~S}$ rRNA real-time PCR revealed asymptomatic infection in $45.6 \%$ and $23.6 \%$ in lambs and ewes, respectively. At the farm level, the prevalence ranged from $0 \%$ to $77.8 \%$ in lambs with significant differences between farms $(p$-value $=1.138 \mathrm{e}-5)$, where farms \#1, \#2 and \#3 prevalence values are significantly higher than farms \#4 and \#5, and from $10.5 \%$ to $50 \%$ in ewes with no significant differences between farms ( $p$-value $=0.1021)$. Many animals found to be negative using microscopy had positive results with DNA detection (data not shown). The prevalence of asymptomatic Cryptosporidium spp. infection was higher in lambs than in ewes (except on farm \#4, where no Cryptosporidium infections were detected in lambs). High between-farm variability was observed for the prevalence. Farm \#3 had the highest prevalence of infection in lambs (77.8\%) and ewes (50\%).

The 18S rRNA sequence analysis from readable electrophoregrams revealed three species: C. parvum, $C$. xiaoi and $C$. ubiquitum. For the rest, analysis showed multiple overlapping traces after a point in the sequence, low/poor signal-tonoise ratio in sequence data, and premature termination of sequences causing unreadable sequences. Cryptosporidium parvum was detected on all farms, $C$. xiaoi on three farms (farms \#1, \#2, and \#3), and C. ubiquitum only on farm \#2. More precisely, $C$. parvum and $C$. xiaoi were identified in both lambs and ewes, whereas $C$. ubiquitum was detected only in ewes. In lambs, $C$. parvum was detected on farms \#3 and \#5 (2/14 lambs and 2/5 lambs, respectively) and C. xiaoi on farm \#2 (1/4 lambs). In ewes, C. parvum was identified on farms \#1, $\# 2$, \#4, and \#5, C. xiaoi was detected on both farms \#1 and \#3, and $C$. ubiquitum was only found on farm \#2.

The Lib13 PCR specifically amplified 10 C. parvum of which three led to gp60 unreadable superimposition of electrophoregrams. Cryptosporidium hominis were not found in this study. Two $C$. parvum gp60 genotype families were identified: IId and IIa. More precisely, three different IId genotypes were detected, IIdA24G1, IIdA21G2, IIdA15G1, as well as two different IIa genotypes, IIaA16G3R1 and IIaA13G2R1. The gp60 IIdA24G1 genotype was detected in lambs on farm \#3 but could not be detected in ewes, if present, due to a failure on gp60 genotyping on this farm.

\section{Discussion}

This study described prevalence of asymptomatic Cryptosporidium infections in lambs and ewes on five farms in the Pyrénées-Atlantiques Department in France. Our study is subject to certain limitations that should be considered when interpreting the results. We recognize a major key limitation of the study is the discrepancies between the number of positive samples detected with the $18 \mathrm{~S}$ rRNA PCR assay and the sequence-based validated isolates. Determining Cryptosporidium species has been impeded by technical limitations. Mixed Cryptosporidium species could explain the sequencing difficulties encountered in this work. The simultaneous presence of several species in the same sample could lead to amplification and sequencing of different genetic fragments, leading to unreadable superimposition of electrophoregrams. However, it is noteworthy that this prospective cohort study 
highlighted, when genotyping could be performed, frequent characterization of $C$. parvum with zoonotic genotypes. Cryptosporidium parvum infections are common in Europe $[28,31,37,42]$, but not on other continents, where $C$. xiaoi and C. ubiquitum predominate [42].

In this present study, despite the high proportion of positive cases detected using the $18 S$ rRNA gene (rDNA)-based primers, sequence analysis showed low signal-to-noise ratios, overlying sequences, and premature termination of sequences, and application of this technique to routine analysis seems complicated. Other studies, using the selected primers, pinpointed sequence homologies with the yeast $18 S$ rRNA gene (GenBank accession number $n^{\circ}$ JN940588.1) [26]. One potential source of bias in our study is detection bias as sample collection was carried out at a single point in time. Adult sheep are known to excrete Cryptosporidium oocysts, but the infection is always asymptomatic with a low level of excretion [30]. Oocyst excretion is known to increase in ewes during parturition and represents a significant source of contamination both for the environment and their lambs $[30,52]$. All the ewes sampled belonged to the first wave of lambing, so their lambs were not in contact with other older lambs. There were, therefore, only two potential sources of contamination for newborn lambs: (i) Cryptosporidium oocysts excreted by the ewes, and (ii) residual contamination of the environment by oocysts from the previous lambing season. The sampling dates, the age of lambs sampled, and the breed (Blond-Faced Manech) were similar; however, the results were highly variable from farm to farm.

Regarding animal management practices, farm \#3 fed lambs artificially. On this farm, lambs, once separated from their mothers, are grouped together to be fed artificially. The density of young and naïve animals is high, which could explain the higher prevalence here than on other farms in lambs, but not in ewes. The other farms have lower prevalence in lambs and ewes with their breeding practices, and the lambs from farm \#4 were not infected with Cryptosporidium spp., with the prevalence of infection being very low in their mothers (12.5\%).

Three Cryptosporidium species were identified in this study: $C$. parvum was frequently detected, $C$. xiaoi and C. ubiquitum were also identified. The latter two species have already been reported in human cryptosporidiosis cases, although the zoonotic potential is certainly much lower than that of $C$. parvum [23].

These species are commonly found in sheep and goats [11, 37, 43]. Cryptosporidium andersoni, which is known to infect sheep [12], was not detected in the present study. Likewise, C. hominis was detected neither in lambs nor in ewes. In rare cases, it can infect goats and sheep [15] but is found with a higher prevalence in calves [38]. As the studied farms were mixed farms with both dairy sheep and meat cattle, we had expected to detect $C$. hominis, but this was not the case. However, Cryptosporidium spp. infections in calves were not investigated during this study.

Regarding $C$. parvum genotypes, two different zoonotic genotype families of gp60 IIa and IId were detected. The presence of these genotypes is well described in sheep and goats [2, 12, 37, 48].

Genotype IIdA24G1 was found only in lambs, consistent with studies performed in north-eastern Europe [19, 37].
In 2010, this genotype caused foodborne outbreaks of cryptosporidiosis in Sweden [14]. The other IId genotype, IIdA15G1, was reported to be common in calves in China $[7,36]$ but not in ewes as in this study. One human case of infection has been reported in a Slovak patient [27], and in cattle and humans in both Iran [29] and the Netherlands [51]. The last IId genotype, IIdA21G2, was found only in ewes in this study. To our knowledge, it has not been reported in the literature, indicating that it could be a new genotype infecting sheep.

Two IIa genotypes were found in ewes: IIaA13G2R1 and IIaA16G3R1. The first genotype has been described in lambs and goat kids in Algeria [2] and calves in Belgium [13]. It was also found in a patient with acute diarrhea in South Korea [24] and in patients from Malaysia with HIV/AIDS [20]. The second one has been reported in lambs and kids with clinical cryptosporidiosis in France [25] and in Spain [10], and more surprisingly in asymptomatic infections in wild ponies of the Iberian Peninsula [6]. This genotype has been found in children in Iran [29] and in sporadic infections in Canada [47] and Australia [50].

Some samples could not be defined at the genotype level due to: (i) insufficient amounts of DNA to have satisfactory quality of genotyping; and (ii) the presence of multiple genotypes of $C$. parvum in the sample, resulting in an illegible electrophoregram. This last point may also be due to mixed co-infections of several genotypes of Cryptosporidium parvum in the sample.

Each farm has a specific association of Cryptosporidium species and genotypes, although the breeding conditions were very similar. On the same farm, infections in lambs and ewes were not identical, some species or genotypes being found in one category of animals only. Several reasons could explain this difference. The first is an underestimation of the number of different Cryptosporidium spp. present in lambs. Clearly, since infections are asymptomatic, only a limited number of oocysts are excreted in feces [30], and the amount of extracted DNA could be insufficient for molecular analysis. In many cases, therefore, the parasites may be present, but the species and genotype cannot be detected.

Furthermore, only a portion of the herd on each farm was sampled and analyzed individually in this study. The results, therefore, reflect the Cryptosporidium species and the genotypes found in a fraction of the animals present on a farm.

The comparison of Cryptosporidium species and genotypes present in ewes and their lambs does not seem in favor of contamination of the lamb only by its mother. Due to the fecal-oral transmission mode of the parasite and its resistance in the environment, lambs can be infected by all Cryptosporidium oocysts excreted by all ewes and present in the environment. Therefore, our sampling effort was probably not sufficient to provide a complete description of Cryptosporidium associations and to better understand the natural transmission of the parasite from ewes to lambs.

\section{Conclusions}

This study investigated Cryptosporidium infections in lambs and ewes on dairy sheep farms in the PyrénéesAtlantiques, France. Molecular analysis revealed asymptomatic 
infection by Cryptosporidium spp. The three Cryptosporidium species identified were $C$. parvum, $C$. xiaoi, and $C$. ubiquitum. In the present study, zoonotic Cryptosporidium parvum IIa and IId genotypes were detected and may highlight the possible role of lambs and ewes as a source of infection, and a potential zoonotic reservoir for human infections. Considering the low number of animals and farms investigated in this study, it would be interesting to confirm these data on other farms. Multiyear monitoring of the same herd could also provide useful information about the evolution of species and genotypes over time.

Acknowledgements. This study was self-funded by the UMT Pilotage de la Santé des Ruminants and the Centre Hospitalier Universitaire, Centre National de Référence des Cryptosporidioses, Rouen (France). It did not receive any specific grants from funding agencies in the public, commercial, or not-for-profit sectors. The participation of the farmers is greatly appreciated.

\section{Conflicts of interest}

The authors declare that there were no conflicts of interest at any point in time.

\section{References}

1. Bailenger J. 1973. Coprologie parasitaire et fonctionelle, 3ème edn. Bordeaux: Drouillard.

2. Baroudi D, Hakem A, Adamu H, Amer S, Khelef D, Adjou K, Dahmani H, Chen X, Roellig D, Feng Y, Xiao L. 2018. Zoonotic Cryptosporidium species and subtypes in lambs and goat kids in Algeria. Parasites \& Vectors, 11, 1-8.

3. Björkman C, Svensson C, Christensson B, De Verdier K. 2003. Cryptosporidium parvum and Giardia intestinalis in calf diarrhoea in Sweden. Acta Veterinaria Scandinavica, 44, 145.

4. Castro-Hermida JA, Pors I, Poupin B, Ares-Mazás E, Chartier C. 2005. Prevalence of Giardia duodenalis and Cryptosporidium parvum in goat kids in western France. Small Ruminant Research, 56, 259-264.

5. Chalmers RM, Campbell BM, Crouch N, Charlett A, Davies AP. 2011. Comparison of diagnostic sensitivity and specificity of seven Cryptosporidium assays used in the UK. Journal of Medical Microbiology, 60, 1598-1604.

6. Couso-Pérez S, de Limia FB-V, Ares-Mazás E, GómezCouso H. 2020. First report of zoonotic Cryptosporidium parvum GP60 subtypes IIaA15G2R1 and IIaA16G3R1 in wild ponies from the northern Iberian Peninsula. Parasitology Research, 119, 249-254.

7. Cui Z, Wang R, Huang J, Wang H, Zhao J, Luo N, Li J, Zhang Z, Zhang L. 2014. Cryptosporidiosis caused by Cryptosporidium parvum subtype IIdA15G1 at a dairy farm in Northwestern China. Parasites \& Vectors, 7, 529.

8. Delafosse A, Castro-Hermida JA, Baudry C, Ares-Mazás E, Chartier C. 2006. Herd-level risk factors for Cryptosporidium infection in dairy-goat kids in western France. Preventive Veterinary Medicine, 77, 109-121.

9. Delafosse A, Chartier C, Dupuy MC, Dumoulin M, Pors I, Paraud C. 2015. Cryptosporidium parvum infection and associated risk factors in dairy calves in western France. Preventive Veterinary Medicine, 118, 406-412.
10. Díaz P, Quílez J, Prieto A, Navarro E, Pérez-Creo A, Fernández G, Panadero R, López C, Díez-Baños P, Morrondo P. 2015. Cryptosporidium species and subtype analysis in diarrhoeic pre-weaned lambs and goat kids from north-western Spain. Parasitology Research, 114, 4099-4105.

11. Fayer R, Santín M. 2009. Cryptosporidium xiaoi n. sp. (Apicomplexa: Cryptosporidiidae) in sheep (Ovis aries). Veterinary Parasitology, 164, 192-200.

12. Feng Y, Ryan UM, Xiao L. 2018. Genetic diversity and population structure of Cryptosporidium. Trends in Parasitology, 34, 997-1011.

13. Geurden T, Berkvens D, Martens C, Casaert S, Vercruysse J, Claerebout E. 2007. Molecular epidemiology with subtype analysis of Cryptosporidium in calves in Belgium. Parasitology, 134, 1981-1987.

14. Gherasim A, Lebbad M, Insulander M, Decraene V, Kling A, Hjertqvist M, Wallensten A. 2012. Two geographically separated food-borne outbreaks in Sweden linked by an unusual Cryptosporidium parvum subtype, October 2010. Eurosurveillance, 17, 20318.

15. Giles M, Chalmers R, Pritchard G, Elwin K, Mueller-Doblies D, Clifton-Hadley F. 2009. Cryptosporidium hominis in a goat and a sheep in the UK. Veterinary Record, 164, 24-25.

16. Glaberman S, Moore JE, Lowery CJ, Chalmers RM, Sulaiman I, Elwin K, Rooney PJ, Millar BC, Dooley JS, Lal AA. 2002. Three drinking-water-associated cryptosporidiosis outbreaks, Northern Ireland. Emerging Infectious Diseases, 8, 631.

17. Hadfield SJ, Robinson G, Elwin K, Chalmers RM. 2011. Detection and differentiation of Cryptosporidium spp. in human clinical samples by use of real-time PCR. Journal of Clinical Microbiology, 49, 918-924.

18. Hunter PR, Nichols G. 2002. Epidemiology and clinical features of Cryptosporidium infection in Immunocompromised patients. Clinical Microbiology Reviews, 15, 145-154.

19. Imre K, Luca C, Costache M, Sala C, Morar A, Morariu S, Ilie MS, Imre M, Dărăbuş G. 2013. Zoonotic Cryptosporidium parvum in Romanian newborn lambs (Ovis aries). Veterinary Parasitology, 191, 119-122.

20. Iqbal A, Lim YAL, Surin J, Sim BLH. 2012. High diversity of Cryptosporidium subgenotypes identified in Malaysian HIV/ AIDS individuals targeting gp60 gene. PLoS One, 7(2), e31139.

21. Jiang J, Xiao L. 2003. An evaluation of molecular diagnostic tools for the detection and differentiation of human-pathogenic Cryptosporidium spp. Journal of Eukaryotic Microbiology, 50, 542-547.

22. Khalil IA, Troeger C, Rao PC, Blacker BF, Brown A, Brewer TG, Colombara DV, De Hostos EL, Engmann C, Guerrant RL. 2018. Morbidity, mortality, and long-term consequences associated with diarrhoea from Cryptosporidium infection in children younger than 5 years: a meta-analyses study. Lancet Global Health, 6, e758-e768.

23. Lefay D, Naciri M, Poirier P, Chermette R. 2000. Prevalence of Cryptosporidium infection in calves in France. Veterinary Parasitology, 89, 1-9.

24. Ma D-W, Lee M-R, Hong S-H, Cho S-H, Lee S-E. 2019. Molecular prevalence and genotypes of Cryptosporidium parvum and Giardia duodenalis in patients with acute diarrhea in Korea, 2013-2016. Korean Journal of Parasitology, 57(5), 531-536.

25. Mammeri M, Cartou L, Chevillot A, Thomas M, Julien C, Vallée I, Polack B, Follet J, Adjou KT. 2019. First identification of Cryptosporidium parvum zoonotic subtype IIaA15G2R1 in diarrheal lambs in France. Veterinary Parasitology: Regional Studies and Reports, 18, 100355. 
26. Mary C, Chapey E, Dutoit E, Guyot K, Hasseine L, Jeddi F, Menotti J, Paraud C, Pomares C, Rabodonirina M, Rieux A, Derouin F, For the ANOFEL Cryptosporidium National Network. 2013. Multicentric evaluation of a new real-time PCR Assay for quantification of Cryptosporidium spp. and identification of Cryptosporidium parvum and Cryptosporidium hominis. Journal of Clinical Microbiology, 51, 2556-2563.

27. Mravcová K, Štrkolcová G, Mucha R, Barbušinová E, Goldová M, Kačírová J, Mad’ar M. 2020. Cryptosporidium parvum zoonotic subtype IIdA15G1 in a Slovakian patient. Annals of Agricultural and Environmental Medicine, 27(3), 485-488.

28. Mueller-Doblies D, Giles M, Elwin K, Smith RP, CliftonHadley FA, Chalmers RM. 2008. Distribution of Cryptosporidium species in sheep in the UK. Veterinary Parasitology, 154, 214-219.

29. Nazemalhosseini-Mojarad E, Haghighi A, Taghipour N, Keshavarz A, Mohebi SR, Zali MR, Xiao L. 2011. Subtype analysis of Cryptosporidium parvum and Cryptosporidium hominis isolates from humans and cattle in Iran. Veterinary Parasitology, 179, 250-252.

30. Ortega-Mora LM, Requejo-Fernández JA, Pilar-Izquierdo M, Pereira-Bueno J. 1999. Role of adult sheep in transmission of infection by Cryptosporidium parvum to lambs: confirmation of periparturient rise. International Journal for Parasitology, 29, 1261-1268.

31. Papanikolopoulou V, Baroudi D, Guo Y, Wang Y, Papadopoulos E, Lafi SQ, Abd El-Tawab MM, Diakou A, Giadinis ND, Feng Y, Xiao L. 2018. Genotypes and subtypes of Cryptosporidium spp. in diarrheic lambs and goat kids in northern Greece. Parasitology International, 67, 472-475.

32. Paraud C, Chartier C. 2012. Cryptosporidiosis in small ruminants. Small Ruminant Research, 103(1), 93-97.

33. Plutzer J, Lassen B, Jokelainen P, Djurković-Djaković O, Kucsera I, Dorbek-Kolin E, Šoba B, Sréter T, Imre K, Omeragić J, Nikolić A, Bobić B, Živičnjak T, Lučinger S, Stefanović LL, Kučinar J, Sroka J, Deksne G, Keidāne D, Kváč M, Hůzová Z, Karanis P. 2018. Review of Cryptosporidium and Giardia in the eastern part of Europe, 2016. Eurosurveillance, 23(4), 1-23.

34. Potters I, Van Esbroeck M. 2010. Negative staining technique of Heine for the detection of Cryptosporidium spp.: a fast and simple screening technique. Open Parasitology Journal, 4, 1-4.

35. Putignani L, Menichella D. 2010. Global distribution, public health and clinical impact of the Protozoan pathogen Cryptosporidium. Interdisciplinary Perspectives on Infectious Diseases, 2010, 1-39.

36. Qi M, Wang H, Jing B, Wang D, Wang R, Zhang L. 2015. Occurrence and molecular identification of Cryptosporidium spp. in dairy calves in Xinjiang, Northwestern China. Veterinary Parasitology, 212, 404-407.

37. Quilez J, Torres E, Chalmers RM, Hadfield SJ, del Cacho E, Sanchez-Acedo C. 2008. Cryptosporidium genotypes and subtypes in lambs and goat kids in Spain. Applied and Environmental Microbiology, 74, 6026-6031.

38. Razakandrainibe R, Diawara EHI, Costa D, Le Goff L, Lemeteil D, Ballet JJ, Gargala G, Favennec L. 2018. Common occurrence of Cryptosporidium hominis in asymptomatic and symptomatic calves in France. PLOS Neglected Tropical Diseases, 12, e0006355.
39. Rieux A, Chartier C, Pors I, Delafosse A, Paraud C. 2013. Molecular characterization of Cryptosporidium isolates from high-excreting young dairy calves in dairy cattle herds in Western France. Parasitology Research, 112, 3423-3431.

40. Robertson LJ. 2009. Giardia and Cryptosporidium infections in sheep and goats: a review of the potential for transmission to humans via environmental contamination. Epidemiology and Infection, 137, 913-921.

41. Santín M. 2013. Clinical and subclinical infections with Cryptosporidium in animals. New Zealand Veterinary Journal, 61, 1-10.

42. Santin M. 2020. Cryptosporidium and Giardia in Ruminants Veterinary Clinics of North America: Food Animal Practice, 36, 223-238.

43. Santín M, Trout JM, Fayer R. 2007. Prevalence and molecular characterization of Cryptosporidium and Giardia species and genotypes in sheep in Maryland. Veterinary Parasitology, 146, $17-24$.

44. Singh BB, Sharma R, Kumar H, Banga HS, Aulakh RS, Gill JPS, Sharma JK. 2006. Prevalence of Cryptosporidium parvum infection in Punjab (India) and its association with diarrhea in neonatal dairy calves. Veterinary Parasitology, 140, 162-165.

45. Striepen B. 2013. Time to tackle cryptosporidiosis. Nature Communications, 503, 189-191.

46. Sulaiman IM, Hira PR, Zhou L, Al-Ali FM, Al-Shelahi FA, Shweiki HM, Iqbal J, Khalid N, Xiao L. 2005. Unique endemicity of cryptosporidiosis in children in Kuwait. Journal of Clinical Microbiology, 43, 2805-2809.

47. Trotz-Williams LA, Jarvie BD, Martin SW, Leslie KE, Peregrine AS. 2005. Prevalence of Cryptosporidium parvum infection in southwestern Ontario and its association with diarrhea in neonatal dairy calves. Canadian Veterinary Journal, 46(4), 349.

48. Tzanidakis N, Sotiraki S, Claerebout E, Ehsan A, Voutzourakis N, Kostopoulou D, Stijn C, Vercruysse J, Geurden T. 2014. Occurrence and molecular characterization of Giardia duodenalis and Cryptosporidium spp. in sheep and goats reared under dairy husbandry systems in Greece. Parasite, 21, 45.

49. Vermeulen LC, Benders J, Medema G, Hofstra N. 2017. Global Cryptosporidium loads from livestock manure. Environmental Science \& Technology, 51, 8663-8671.

50. Waldron LS, Ferrari BC, Power ML. 2009. Glycoprotein 60 diversity in $C$. hominis and $C$. parvum causing human cryptosporidiosis in NSW, Australia. Experimental Parasitology, 122(2), 124-127.

51. Wielinga PR, de Vries A, van der Goot TH, Mank T, Mars MH, Kortbeek LM, van der Giessen JWB. 2008. Molecular epidemiology of Cryptosporidium in humans and cattle in The Netherlands. International Journal for Parasitology, 38(7), 809-817.

52. Xiao L, Herd RP, McClure KE. 1994. Periparturient rise in the excretion of Giardia sp. cysts and Cryptosporidium parvum oocysts as a source of infection for lambs. Journal of Parasitology, 80, 55

53. Xiao L, Morgan UM, Fayer R, Thompson RCA, Lal AA. 2000. Cryptosporidium systematics and implications for public health. Parasitology Today, 16, 287-292.

54. Ye J, Xiao L, Wang Y, Wang L, Amer S, Roellig DM, Guo Y, Feng Y. 2013. Periparturient transmission of Cryptosporidium xiaoi from ewes to lambs. Veterinary Parasitology, 197, 627633.

Cite this article as: Bordes L, Houert P, Costa D, Favennec L, Vial-Novella C, Fidelle F, Grisez C, Prévot F, Jacquiet P \& Razakandrainibe R. 2020. Asymptomatic Cryptosporidium infections in ewes and lambs are a source of environmental contamination with zoonotic genotypes of Cryptosporidium parvum. Parasite 27, 57. 
An international open-access, peer-reviewed, online journal publishing high quality papers on all aspects of human and animal parasitology

Reviews, articles and short notes may be submitted. Fields include, but are not limited to: general, medical and veterinary parasitology; morphology, including ultrastructure; parasite systematics, including entomology, acarology, helminthology and protistology, and molecular analyses; molecular biology and biochemistry; immunology of parasitic diseases; host-parasite relationships; ecology and life history of parasites; epidemiology; therapeutics; new diagnostic tools.

All papers in Parasite are published in English. Manuscripts should have a broad interest and must not have been published or submitted elsewhere. No limit is imposed on the length of manuscripts.

Parasite (open-access) continues Parasite (print and online editions, 1994-2012) and Annales de Parasitologie Humaine et Comparée (1923-1993) and is the official journal of the Société Française de Parasitologie. 